\title{
DEVELOPING A TEACHING PHILOSOPHY FOR A TEACHING CREDENTIAL
}

\author{
David Woodward, Bronwyn Hegarty, Elise Allen, Shannon Booth, \\ Sarah Redfearn, Sarah Smith, Karen Wakelin, and Jayne Webster
}

\section{INTRODUCTION}

A critical component of the Graduate Diploma in Tertiary Education (Level 7) (GDTE) teaching credential is the development of a Teaching Philosophy Statement as an expression of a professional framework of teaching practice. This statement is a narrative description of beliefs, values, rationale and insights into learning and teaching, and how these inform teaching (Schonell et al., 2016, p. 4).

A group of recent GDTE graduates, representing both the taught, Recognition of Prior Learning (RPL) and Independent Learning Pathway (ILP) programmes at Otago Polytechnic, was brought together as a Community of Practice (CoP) to collaborate on an article. Participants in the taught programme had studied a series of courses and included teachers relatively new to tertiary teaching. Two experienced teachers undertook the RPL pathway some course work and some RPL - and two other experienced teachers undertook the ILP (CapableNZ).

The catalyst for this article was the 2018 Capable NZ Professional Practice Symposium, where examples of Teaching Philosophy Statements and the process to prepare them was discussed (Woodward, Hegarty, Allen, \& Redfearn, 2018). The audience was introduced to the use of metaphor and established frameworks, such as those by Chism (1998) and Schönwetter, Sokal, Friesen and Taylor (2002), for structuring Teaching Philosophy Statements.

The aim of the article is to articulate the process of developing a model of professional teaching practice expressed through the Teaching Philosophy Statement, illustrating how this can provide evidence for a tertiary teaching credential. Example quotes from the Teaching Philosophy Statements of collaborating teachers are used to illustrate different approaches and the uniqueness of professional practice. To compile the article, our CoP was tasked with considering three key questions.

I. Why is the development of a Teaching Philosophy Statement critical to the establishment of a tertiary teaching model of practice?

2. How does a Teaching Philosophy evolve when studying for a tertiary teaching credential?

3. Why is the Teaching Philosophy Statement an important component of credentialing for tertiary teaching?

Through critical reflection, the CoP considered key influences on the process of developing a Teaching Philosophy Statement as partial evidence for the GDTE credential. This participation helped them to explore aspects of their own teaching practice post-GDTE. For example, how their learning for the credential has impacted on their everyday teaching practice. 


\section{WHAT IS THE PURPOSE OF A TEACHING PHILOSOPHY STATEMENT?}

A Teaching Philosophy Statement represents 'who you are' as a teacher and the factors driving practice. It is reflective, unique to each individual, and generally written in first person as a narrative containing specific examples of teaching practice (Center for Excellence in Learning and Teaching, lowa State University, n.d.). To express a teaching philosophy requires a good understanding of individual teacher identity, and the ability to articulate why teaching and learning occurs in a particular way.

Sarah S and Jayne felt that understanding their teaching philosophy allowed them to articulate it to others. Jayne tells students about her teaching philosophy in an overt way and this helps to justify her flexible teaching pedagogy. Shannon thought the Teaching Philosophy Statement was a really powerful exercise, highlighting why things are done, and creating relevance for adult learners (Knowles, 1980). She plans to use her Teaching Philosophy Statement when she applies for a teaching role in the future as it will help paint a picture of the type of teacher she is, and how she views the learning process.

Elise felt that having a teaching philosophy informed her lesson planning and course design, forming the basis for how she teaches in the classroom. Sarah $\mathrm{S}$ uses her teaching philosophy to guide how she works alongside academic staff in workshops. Sometimes she will lead the way and at other times she will sit back and let others take the lead, only stepping in when required. This illustrates the concepts of Ako, Mātauranga Māori and Tuakana - Teina which are central to her philosophy.

As can be seen, each practitioner understands the value of constructing a Teaching Philosophy Statement and the purpose of having it. How they would use it varied amongst the group.

\section{THE PROCESS, ENABLERS AND CHALLENGES}

Commonalities emerged in the way members of the CoP began the process of preparing their Teaching Philosophy Statements. Shannon, Sarah R, and Sarah S used biographical experiences to explore and identify recurring themes and significant moments that were important to them in their own teaching and learning experiences. Once these themes were identified they went back and read examples of other Teaching Philosophy Statements to determine structure and format and to find headings that resonated. Thus, they developed a "framework of 'hooks' to hang ideas on." Through a process of linking elements of the Teaching Philosophy Statement and their own experience, they were able to articulate and refine a finished statement which had meaning and purpose.

Shannon's first step was to spend time writing her autobiography:

This was a really helpful process as it revealed recurring themes that really highlighted what was important to me. It opened my eyes to the reasons I do things the way I do - I could see that my 'common sense' practices suddenly had a real purpose behind them.

An excerpt from Shannon's Teaching Philosophy Statement describes an early learning experience and the influence of this on her career as an educator.

Maya Angelou's words ring true to me when she said "people may not always remember what you said or did, but they will remember how you made them feel."

This is what originally drew me towards pursuing a career in teaching - because of the positive way certain teachers made me feel about myself and my potential. For this reason, to me, the focus of learning and teaching is not just on the transfer of knowledge, but it is about the relationships you can build, and the feelings of positive empowerment that educators can rouse in people; the way you can help a 
learner to walk out of your learning environment feeling lifted, reassured, prepared, encouraged, confident and good about themselves. I want to be an educator

because I believe educators are in the perfect place to do all of these things, and so much more!

(Shannon Booth, 2018).

The most important initial step for Elise was talking to colleagues as this was a naturally occurring part of her practice: "... we like to talk about teaching challenges and approaches and metaphor always comes into it." Jayne found listening to others an essential starting point, and then reading around the topic, and making notes on what was important to her specifically. However, Shannon found that looking at other examples was too confusing as each one was different and failed to resonate with her own teaching experiences. This confusion occurred because there was no set way to write one. Also, the exemplars were situated within different teaching disciplines and countries, and represented an unfamiliar teaching culture. Conversely, Karen found that the various examples she encountered, spurred her creativity when structuring her statement. In other words, she felt it was okay to create something unique to her.

One of the challenges for Sarah S was to find evidence to support what she was doing as a teacher. She knew that what she was doing worked, but had difficulty articulating why. Refreshing her memory of educational learning theories from her primary teacher training helped to inform her Teaching Philosophy Statement and allowed her to develop a deeper understanding of where these theories sat with her in the present, after years of teaching.

Sarah $\mathrm{R}$ found developing a teaching philosophy a very personal process which sometimes meant it was difficult to articulate the ideas she held in a way that conveyed the depth behind them. She also felt vaguely self-conscious about others reading her Teaching Philosophy Statement as it felt like she was laying her soul bare a little bit! Like others, she connected elements of a teaching philosophy to her previous experiences. For her, learner-centeredness was closely related to 'client or person-centeredness' in the mental health field. Carl Rogers' (1995) ideas and work had influenced Sarah R's approach to working relationships in her occupational therapy training and practice, and the philosophy of the therapeutic community and motivational interviewing transferred naturally to the classroom situation. Also, she was drawn to the writings of Knowles, Holton and Swanson (2005) on adult education which echoed many of her own experiences and observations over the years. Therefore, she held the belief that learning should be a creative process whereby a learner has the opportunity to link previous experience to new knowledge, play with ideas and concepts, and ultimately contribute to their knowledge of self. This also connects to Maslow's (1954) concept of self-actualisation.

As experienced teachers engaging in the IPL, both Shannon and Sarah R prepared a Teaching Philosophy Statement as part of their portfolio of work. In contrast, other members of the CoP studied the final capstone course in the GDTE, Integration of Professional Practice for Teaching, where preparation of a Teaching Philosophy Statement was required as an assessment task. Regardless of the study pathway taken, reflecting on teaching practice was an important aspect of the journey, and they all developed a metaphor to express their philosophy.

\section{Using metaphor to express a teaching philosophy}

The CoP was attracted to the use of metaphor as a means of expression, either because they already viewed teaching within a metaphorical context such as coaching (Elise), had been in a guiding role previously (Sarah S), or discovered this approach during the preparation phase. Shannon, Karen, Sarah R and Jayne saw the use of metaphor as a visual expression of what was important to them as teachers and something that others would understand.

Quotes from their Teaching Philosophy Statements illustrate how they used metaphor to express their teaching identities and practice. 


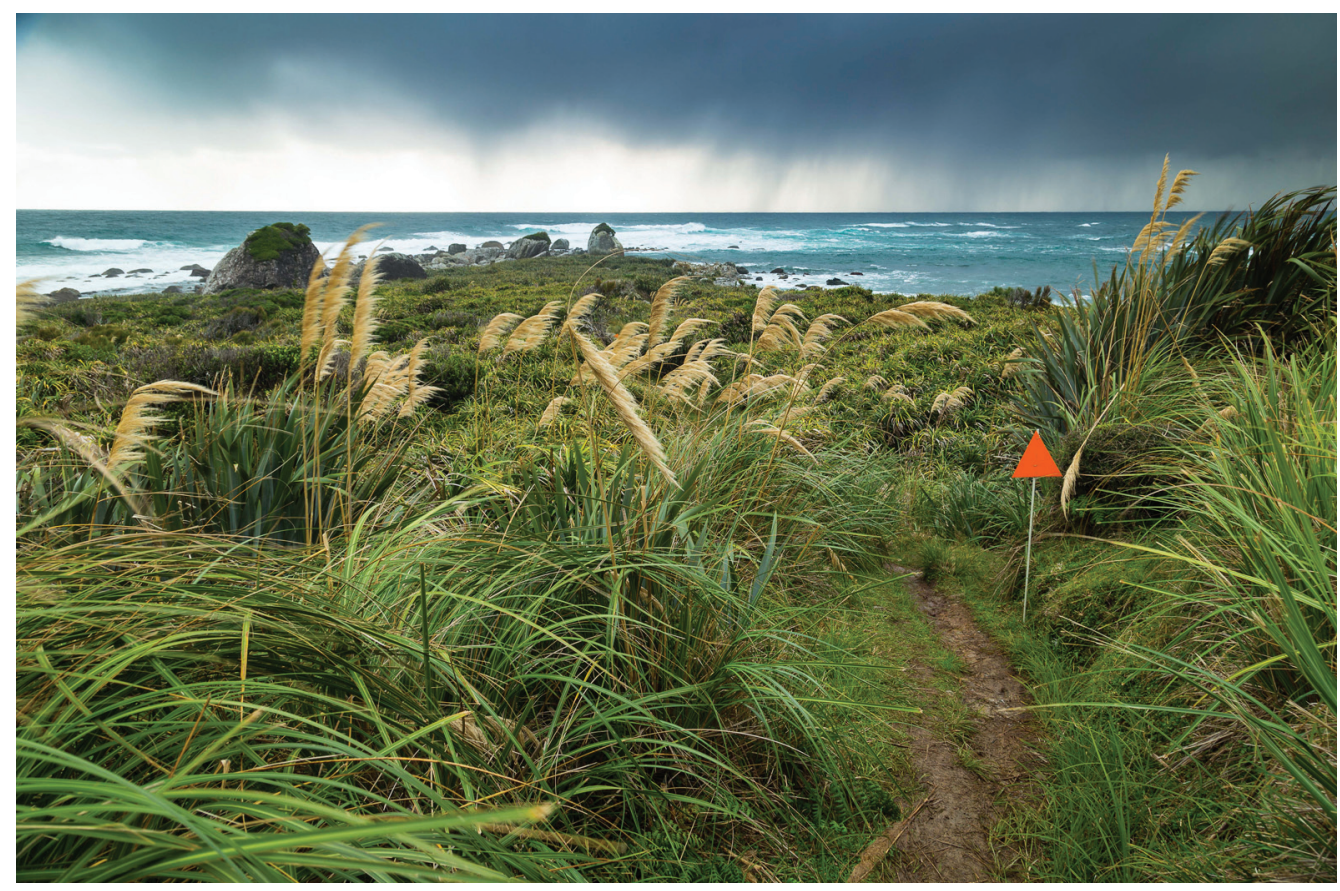

Figure I.Track marker. Source: Sarah K Smith photography.

Karen likened her teaching to a bush walk, because she enjoyed this activity in her spare time. She saw the path of teaching as ever changing due to environmental influences, and conditions which could be both challenging and rewarding. Here is an excerpt from Karen's Teaching Philosophy Statement:

I see my definition and journey of teaching very much as going on a bush walk. Sometimes the paths are clear and other times sign posts or a compass are needed to guide you in the right direction. I will continually check in with the students (similarly to using a compass) to ensure both I and them are going in the right direction. Along the way, there may be some water falls or interesting sites to look at which symbolise the insightful learning that takes place with learners, when engaged in discussions which encourage everyone to look at something from a different point of view. At times, these discussions may be around some challenging issues within practice that students have identified and so through discussion together we negotiate the path (or direction) we will go in. At other times, the path takes you down-hill - which is easier and more comfortable, such as when facilitating the learning of new skills that student midwives will then take with them into the clinical environment.

Ultimately, the path leads us to our destination - some will take longer to finish than others, and some will notice things that others may not. All our experiences are different, and how we ultimately reach our destination will be different from one day to the next. The important thing though, is the learning and experience along the way.

(Karen Wakelin, Teaching Philosophy Statement, 20।8.) 
One of the biggest enablers that assisted Karen with writing her Teaching Philosophy Statement stemmed from her underlying belief that as a 'teacher' she was working in partnership with the learners. As a midwife, she had a philosophy based on partnership whereby midwives and women work together, each bringing their own knowledge, skills and experiences together to share a journey. Her work with midwifery students, who would one day become her midwifery colleagues, helped to shape not only her interactions with students, but how she saw her role as an educator. As a new teacher, this process helped her to influence her ideas on the meaning of being a tertiary educator. At times she was walking alongside the students as they paved their way together, while at other times, she was in the front or at the back, having passed the compass to others to enable them to take the lead.

An important point to consider here is the connection between the teaching philosophy and the teacher's subject matter expertise, including ethical codes of practice, perceptions of relationships and foreseen outcomes for the learners. In some cases, the evidenced-based theories supporting both teaching and the teacher's area of expertise, in this case midwifery, may be very similar, for example, humanism theory (Maslow, 1943). One of the challenges for Karen was due to the newness of her role as an educator, and she did not have a lot of 'formal teaching' experiences to draw on when writing her Teaching Philosophy Statement. Therefore, for Karen, it was very much about identifying her philosophy based on what she had learnt through undertaking the GDTE, and from colleagues and other students.

Sarah $\mathrm{S}$ also saw herself as a guide on a journey with learners:

Like a professional walking guide, the teacher respectfully and compassionately guides learners so they have a positive, fun, safe and potentially life changing experience. The teacher walks with them, developing a congenial relationship, conversing, sharing thoughts and experiences, ideas and philosophies. The teacher points out things of interest to the whole group when leading from the front and simply observes when they are at the back, ready to step in if the learners miss a critical turn off or safety becomes an issue. All the while, the teacher is developing an understanding of the learner's goals while keeping them on track and safe, emotionally and physically.

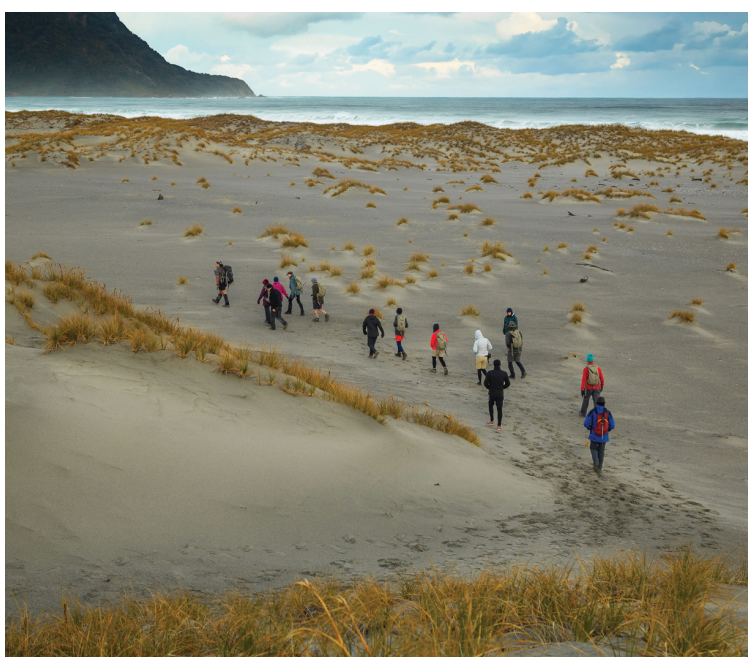

Figure 2. Guiding a group. Source: Sarah K Smith photography.
During these experiences, they learn from each other, experience personal challenges and learn that flexibility is required. In doing this they engage the concepts of Ako and Tuakana-Teina.Ako, "where the educator is also learning from the student and where educators' practices are informed by the latest research and are both deliberate and reflective" (Ministry of Education, n.d., para. I). Tuakana-Teina is where "An older or more expert tuakana (brother, sister or cousin) helps and guides a younger or less expert teina" (Ministry of Education, n.d., para. I) (Sarah Smith, Teaching Philosophy Statement, 2018). 
In contrast, Shannon likened her teaching ethos to being a diamond of four equal sides:

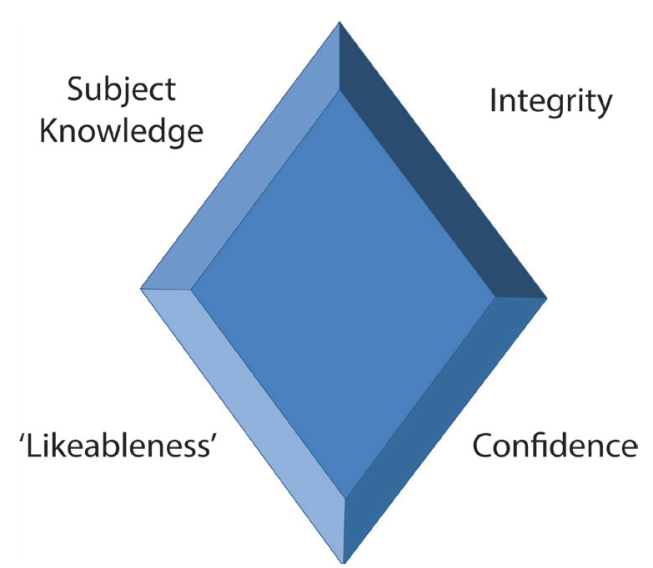

Figure 3. Booth, Shannon. (2019). Diamond diagram.
On one side of the diamond is my subject knowledge and the competence I have in conveying this knowledge. On another side is my integrity - my honesty, my reliability, my professionalism.

On a third side is my 'likeableness' - an umbrella term that encompasses many aspects, including my ability to earn respect, build rapport, relate to people, develop relationships, engagement, openness, authenticity and 'keeping it real'.

The final side is my confidence. This is an aspect of the diamond that I have worked really hard on since I started my teaching journey back in 2001.

To teach effectively, I want all four sides of my diamond to sparkle brightly.

(Shannon Booth, Teaching Philosophy Statement, 2018.)

The challenge for Shannon, being a kinaesthetic learner, was not being able to visualise her finished product to get an idea of where she should be heading. She soon realised that each person's Teaching Philosophy Statement was different and that there was no right or wrong way to write one but rather an accepted format, and this meant keeping it short and to the point. Shannon found that keeping the statement to just a few pages was a big challenge.

For Jayne, the metaphor that resonated was Punakaiki (Pancake Rocks) with the elements surrounding the National Park of Paparoa. She stated:

Flexibility is also a key part of my teaching philosophy, whether it be in the classroom or what happens in the students' life. The wind, rain and elements affect Punakaiki with the waves having an effect on the view of the rocks and surroundings, and flexibility of the traveller (or me as the teacher in this case) might mean I need to change a lesson plan in the moment, or how I am teaching the content... For me, it is important to meet the lesson outcomes but how this is done will vary depending on the student, time and the context. It means that I can inject my own enthusiasm to motivate students but using my own examples (e.g. in mental health, particularly relating to the inpatient unit, I will get students to set up a sensory room and then give a scenario that happened and students will work through what they would do through group discussion). This relates to a number of Kember and McNaught (2007) principles of effective teaching with discussion, motivating students, enthusiasm and interesting, enjoyable activities.

(Jayne Webster, Teaching Philosophy Statement, 2018)

For Jayne, an experienced teacher, the challenge was to articulate in writing what she wanted to say realising that this was based on her own values and beliefs. 


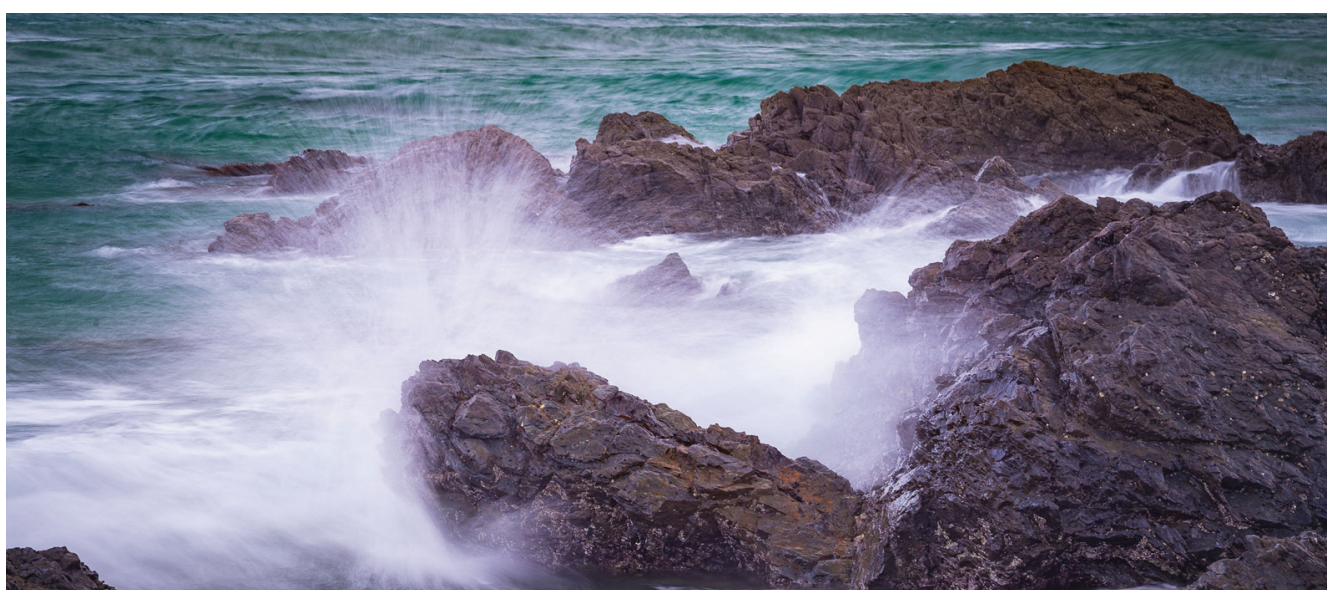

Figure 4. Waves and rocks, Punakaiki. Source: Sarah K Smith photography.

Sarah R connected with metaphor through her discipline and the art of giving feedback in clinical supervision. She likened feedback to the effects of fire: warm, fuzzy, smoky or a spark of energy. This got her thinking about the fire triangle and the idea there are elements that depend on each other for the whole to work. She was able to relate that to the ingredients or conditions needed to get learning happening.

These examples of metaphors from the authors' Teaching Philosophy Statements have hopefully made it easier for you, the reader, to visualise what teaching means to each person and how they view their role and the relationship with learners. Metaphors are known to be an effective communication tool and have been well researched in teacher education as a means of expression (Northcote \& Fetherston, 2006). As a symbolic representation, metaphors can be used to both influence and interpret teaching practice by facilitating an exploration of beliefs about teaching and learning (Northcote \& Fetherston, 2006). Choosing a

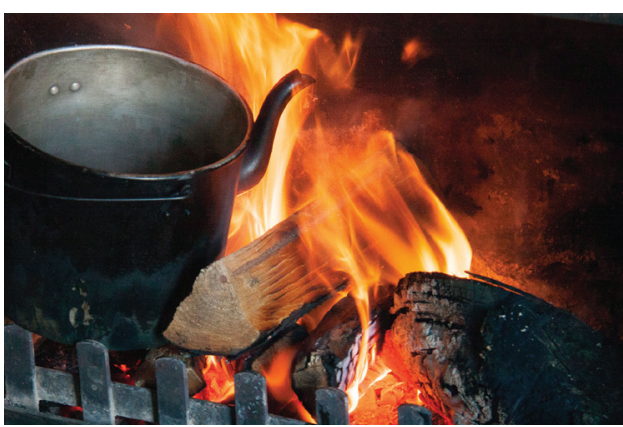

Figure 5. Fire. Source: Sarah K Smith photography. metaphor, in the first instance, is a reflective process, as is the process of connecting the elements or components to identity individual beliefs about teaching and their unique style. Using metaphor to prepare a Teaching Philosophy Statement requires an insightful examination of personal practice, and a look at others' perspectives through a lens of critical reflection. Metaphor as an expression of a teaching philosophy is not always an easy process, and can often be messy and inexact (Northcote \& Fetherston, 2006). Even so, members of this CoP found the use of metaphor helped them to understand their teaching better and enabled them to articulate their philosophy in a way that made sense. They found it a creative and meaningul process and one that connected them with teaching and also with their wider professional practice.

According to research, the choice of metaphor can reveal a great deal about a teacher's practice, and a trend in the type of metaphor chosen has emerged to show that teaching and learning is increasingly regarded as an integrated and complex process rather than two separate entities (Northcote \& Fetherston, 2006). For example, where learning is seen as a journey, the teacher becomes a guide to facilitate this rather than a deliverer of information to the learners who are seen as receptacles or receivers of knowledge. 


\section{OTHER FRAMEWORKS}

Sometimes using metaphor alone to create a narrative for a Teaching Philosophy Statement is not enough and as Elise and Karen found they also needed to use Schönwetter's framework (Schönwetter et al., 2002) to structure their metaphors. Karen likened the preparation of her statement to a meandering bush walk where she felt she was wandering aimlessly at first. She felt she needed to find some structure and so after several drafts, found that incorporating the bush walk metaphor structured under the headings of Schönwetter's framework (Schönwetter et al., 2002) helped to keep her focused and provided some direction.

Schönwetter's framework (Schönwetter et al., 2002) is based on six components: (I) definition of teaching, (2) definition of learning, (3) perception of the learner, (4) student-teacher relationship, (5) teaching methods, and (6) evaluation and impact (see Figure 6). In this framework, teachers are able to use the components to examine their beliefs and practice and to set goals for their future growth and development as teachers.

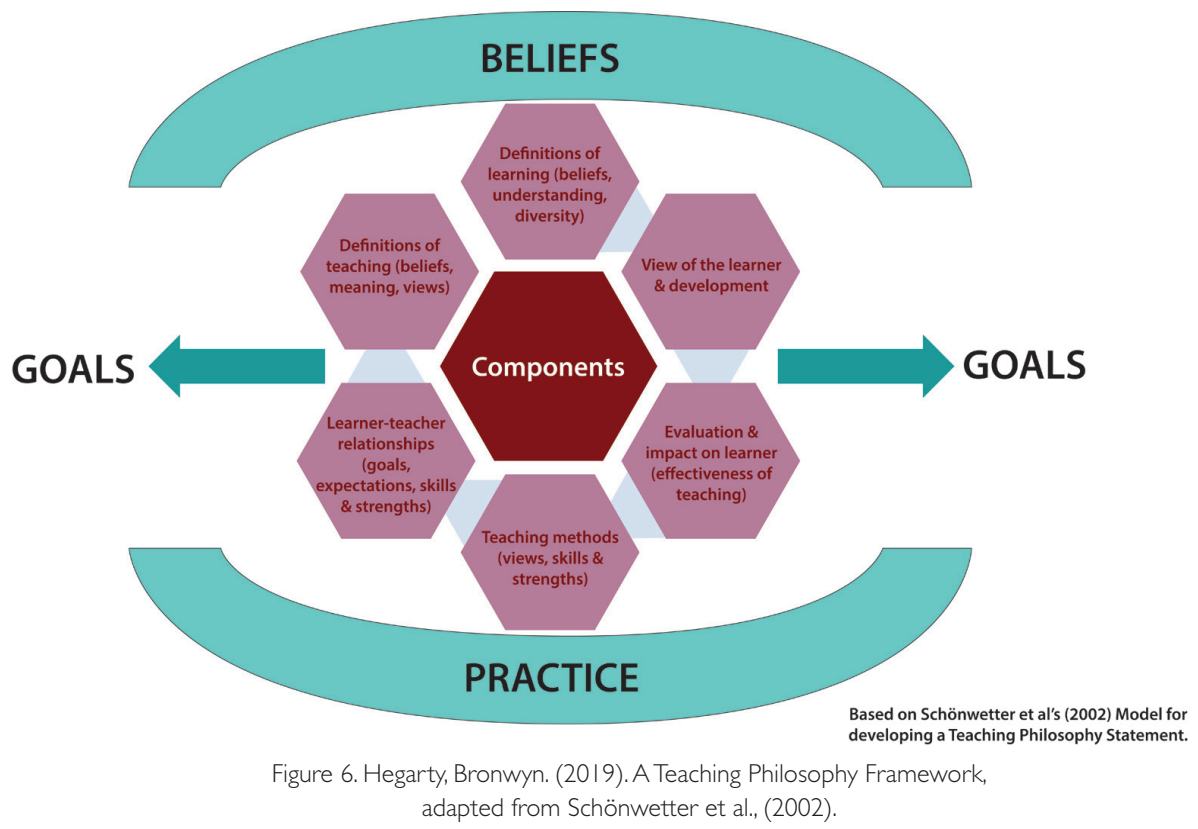

Developing a Teaching Philosophy Statement, regardless of the process, is a journey in itself, and one that the group found personally fulfilling.

\section{CREDENTIALING AND THE IMPORTANCE OF A TEACHING PHILOSOPHY STATEMENT}

Teaching is a scholarly profession with the potential to transform society through educative practices that make a difference to peoples' lives. For this to happen, teachers themselves need to be educated and learn how to become effective practitioners. A credentialing process provides the vehicle that can transport the novice teacher towards proficiency, and eventually find expert status as an experienced practitioner. For this metamorphosis, a teacher must first be aware of their teacher identity or 'who they are as a teacher.' With this identity comes an awareness of what drives their practice, their values, beliefs and assumptions, and this is the beginning phase of developing a Teaching Philosophy Statement. This philosophy is the guiding light for teachers' behaviours - what they do, why they do it, and how they do it. Some people might liken this to an ideology or a perspective but a teaching philosophy is the fundamental driving force for teaching, whether the teacher realises it or not. 
During their study for a tertiary teaching credential, both novice and experienced teachers discovered their 'wings' as teachers through the process of developing a Teaching Philosophy Statement. This was a challenging process, and took time to evolve. Was it worth it? We believe the illustrative quotes speak for themselves, and show these teachers are passionate about what they do. They want to be effective teachers and they care about their learners, and this alone will help to provide a fertile environment for learning and the development of knowledge.

The Teaching Philosophy Statement is a reflection of the framework of practice that defines an educator. It is more than just an ideology about teaching, and is evidence-based, informed by established educational theories, and models of learning and teaching. The development of a personalised Teaching Philosophy Statement during credentialing is an empowering experience. In undertaking such a self-reflective process, an individual may reach what Maslow (1943) describes as the level of self-actualisation; realizing personal potential and self-fulfillment, while seeking personal growth and peak experiences. At this level, it may be possible to share knowledge with others in an impartial, inclusive, nurturing, guiding, and coaching manner, to remove barriers to learning and pave the way for knowledge acquisition.

Educators can be seen as role models, enacting social cognitive learning theory (Bandura 1986). As such, a teacher's view of the world can model behaviours that are reflective of society as a whole. A teacher can impact others through teaching by virtue of societal influences, such as race, culture, religion and economic status. From a critical theory perspective (Horkheimer, 1972), we could say that teachers reflect societal norms, even if somewhat critical of them, helping others to feel empowered and reach a point of self-actualisation. It could be argued, therefore, that a Teaching Philosophy Statement might reflect the desire to develop similar attributes in learners. If this is true, then educators are, in a sense, striving for liberation and emancipation in their learners, rather than human enslavement and manipulation. Teachers could be viewed not only as facilitators of knowledge acquisition in learners, but also as guides along a path of self-fulfilment, enabling learners to realise their personal potential. The development of a Teaching Philosophy Statement as part of a teaching credential, can therefore be seen as an integral catalyst to support this process.

\section{CONCLUSIONS}

The cornerstone for establishing a framework of practice and achieving a teaching credential is an awareness of an individual philosophy of teaching. The Teaching Philosophy Statement is the centrepiece in this process, informed by pedagogical theory and practice. Three questions were explored in this article and the authors established a number of concepts.

Firstly, the development of a Teaching Philosophy Statement is critical to the establishment of a tertiary teaching model of practice because it defines the educator and is empowering in helping the practitioner to reach selfactualisation.

Secondly, the evolution of the teaching philosophy linchpin may come from reading other statements or by talking with colleagues in a CoP of like-minded teachers, and is best assisted by a facilitator.

Thirdly, the use of metaphor is important as a vehicle for expression.

Fourthly, critical reflection through writing an autobiography helps to tease out recurring themes in past teaching and learning experiences.

Fifthly, this process, when coupled with an exploration of pedagogical theories and practice, appears to provide the catalyst for the development of a Teaching Philosophy Statement. 
From a social perspective, teachers transform lives and in many societies they are held in the highest esteem as the font of all knowledge. Fundamental to this, in western society, is a teaching credential that enables development of effective practitioners. It is the credentialing process that provides the vehicle for scholarship. At the core of the achievement of a teaching credential lies the development of a Teaching Philosophy Statement as an expression of identity, ideology and self-belief, underpinned by pedagogical theory and practice. Teaching practitioners are facilitators of knowledge acquisition in others, and can potentially model societal norms while guiding learners towards self-actualisation. However, to do this, they need to explore their own values, beliefs and assumptions, and develop a critical understanding of the foundations for their practice.

\section{Recommendations}

- Developing an autobiography is one method teachers can use to reflect on their values, beliefs, assumptions, and goals.

- Studying for the GDTE credential provides a vehicle for the development of a Teaching Philosophy Statement.

- Teachers find metaphors an easy way to visualise and articulate their teaching practice when building a framework for their teaching philosophy.

- Developing a sound knowledge of educational theories and models enables teachers to select relevant principles to inform their unique philosophy of teaching. This evidence-based approach provides a solid foundation on which teaching practice can flourish.

- Teachers with years of experience may be able to evaluate what pedagogical practice has worked successfully in the past and connect this to theory. Novice teaching practitioners will need guidance to develop this aspect.

- A CoP provides a rich environment for teaching practitioners to discuss and share ideas about teaching philosophies helping them to develop a meaningul statement of teaching practice.

Dr David Woodward is a facilitator, assessor and academic mentor at Capable NZ (Graduate Diploma in Tertiary Education, Bachelor of Applied Management, Master of Professional Practice, Doctor of Professional Practice), part-time lecturer in apiculture, Central Otago campus and company director. His background: includes an MSc (Hons) in botany, PhD in zoology, research scientist Adelaide University, state apiculture advisor for South Australia, head of apiculture at Telford, and over 20 years tertiary teaching experience.

Dr Bronwyn Hegarty has been a principal lecturer in the Graduate Diploma in Tertiary Education for seven years. She has worked with tertiary teachers, developing their capability through the qualification and by supporting their engagement in work-based learning projects and research. Her research has explored the evaluation of eLearning, mobile learning, eportfolios, reflective practice and digital information literacy. Previously, she helped lead eLearning staff development in the Institutes of Technology and Polytechnic sector.

Elise Allen is a senior lecturer in Web Development, Software Engineering, User Experience Design and Professional Practice in the Bachelor of Information Technology programme at Otago Polytechnic. Her current areas of interest include experiential learning, 'Agile' practices, industry workflows in the classroom and studio-based learning for technology subjects. 
Sarah Redfearn has had a 25 year career as an occupational therapist working in forensic psychiatry and addictions treatment both in the UK and New Zealand. She joined the Otago Polytechnic Occupational Therapy School three years ago and completed the Graduate Diploma in Tertiary Education qualification last year.

Shannon Booth joined the College of Community Development and Personal Wellbeing at Otago Polytechnic three years ago. Shannon has previously worked as a secondary school teacher and has held various adult education roles over the past nine years specialising in the areas of pregnancy, childbirth and parenting education, and women's health and wellbeing.

Sarah Smith entered education 21 years ago and has been teaching and designing learning experiences in the tertiary sector for eight and a half years. She joined Otago Polytechnic in 2015 as a Learning and Teaching Facilitator as part of the Designing for Learner Success (D4LS) initiative and now works as a Learning and Teaching Specialist in the Learning and Teaching Development Team. Sarah completed the Graduate Diploma in Tertiary Education and a Graduate Certificate in Instructional Design at Royal Roads University in 2019.

Karen Wakelin is a Senior Midwifery Lecturer on the Bachelor of Midwifery and Post-graduate Midwifery programmes at Otago Polytechnic, along with supervising Master of Midwifery research. Karen has worked extensively throughout various aspects of midwifery practice both within the community and hospital, working as a midwife and in midwifery management/leadership roles.

Jayne Webster is a senior lecturer at the School of Occupational Therapy, Otago Polytechnic based at the Hamilton site. Jayne has been involved in teaching, curriculum development and student support over the past 10 years. As an occupational therapist, Jayne's practice interests are in mental health, developmental disabilities and sensory processing. 


\section{REFERENCES}

Bandura, A. (1976). Modelling theory. In W. S. Sahakian (Ed.), Learning: systems, models, and theories (2nd ed., pp. 39I-409). Skokie, IL: Rand McNally.

Bandura, A. (1986). Social foundations of thought and action: a social cognitive theory. Englewood Cliffs, NJ: Prentice Hall.

Center for Excellence in Learning and Teaching, lowa State University. (n.d.). Writing a Teaching Philosophy Statement. Retrieved from https://www.celt.iastate.edu/teaching/document-your-teaching/writing-a-teaching-philosophy-statement/

Chism, N. V. N. (1998). Developing a philosophy of teaching statement. Essays on Teaching Excellence, 9(3), I-2. Professional and Organizational Development Network in Higher Education. Retrieved from http://ucat.osu.edu/wordpress/assets/V9-N3Chism.pdf

Horkheimer, M. (1972). Critical Theory. New York: Seabury Press; reprinted Continuum: New York, 1982.

Kember, D., \& McNaught, C. (2007). Enhancing University Teaching: Lessons from Research into Award Winning Teachers. Abingdon, Oxfordshire: Routledge, UK.

Knowles, M. S. (1980). The modern practice of adult education: From pedagogy to andragogy. (2nd ed.). New York: Cambridge Books.

Knowles, M. S., Holton, E. F. \& Swanson, R. A. (2005). The adult learner: The definitive classic in adult education and human resource development. San Diego: Elsevier.

Maslow, A. H. (1943). A Theory of Human Motivation. Psychological Review 50(4), 370-96.

Maslow, A. H. (1954). Motivation and personality. New York: Harper and Row.

Northcote, M. T., \& Fetherston, T. (2006). New metaphors for teaching and learning in a university context. Paper presented at the Higher Education Research and Development Society of Australasia Conference, Perth, Australia. Retrieved from https:// research.avondale.edu.au/edu_conferences/I8/

Ministry of Education. (n.d.). Ako: The concept of ako. Retrieved from http://tereomaori.tki.org.nz/Curriculum-guidelines/Teachingand-learning-te-reo-Maori/Aspects-of-planning/The-concept-of-ako

Ministry of Education. (n.d.). Tuakana-Teina: The concept of tuakana-teina relationship. Retrieved from http://tereomaori.tki.org.nz/ Curriculum-guidelines/Teaching-and-learning-te-reo-Maori/Aspects-of-planning/The-concept-of-a-tuakana-teina-relationship

Rogers, C. (1995). Client-Centered Therapy. Its Current Practice, Implications and Theory. New York: Constable \& Robinson Ltd.

Schonell, S., Gilchrist, J., Kennelly, R., McVormack, C., Northcote, M., Ruge, G., \& Treolar, G. (2016). Talking about teaching and learning (TATAL): Teaching Philosophy workbook. Hammondville, NSW: Higher Education Research and Development Society of Australasia (HERDSA).

Schönwetter, D. J., Sokal, L., Friesen, M., \& Taylor, K. L. (2002). Teaching philosophies reconsidered: A conceptual model for the development and evaluation of teaching philosophy statements. International Journal for Academic Development, 7( I), 83-97. Doi http://dx.doi.org/10.1080/|360|44021015650 |

Woodward, D., Hegarty, B., Allen, E., \& Redfearn, S. (2018). Developing a Teaching Philosophy. Capable NZ Professional Practice Symposium. Theme: Exploring professional futures. II December 2018, Otago Polytechnic.

\section{Image attributions}

Bastian. (20I I). Pancake Rocks Blowhole. Retrieved from https://flic.kr/p/9s6DRA

Booth, Shannon. (2019). Diamond diagram.

Hegarty, Bronwyn. (2019). A Teaching Philosophy Framework.

Kinghorn, Jocelyn. (20/3). Follow looking towards the village. Retrieved from https://flic.kr/p/ij33PK

Kularatne, Mahesh. (2009). Fire. Retrieved from https://flic.kr/p/7eP7Mt

Murray. (20I5). Butterfly Creek track. Butterfly Creek Walk: Wellington Walks. The Outdoor Den. Retrieved from https://theoutdoorden.com/butterfly-creek-walk 